\title{
Comparative Advantages and Limitations of Qualitative Strategy of Comparison as Applied to Russian Cases of Perestroika Period's Representation in History Textbooks
}

\author{
Alexander Ivanovich Gorylev ${ }^{1}$, Natalia Damirovna Tregubova ${ }^{2} \&$ Sergiy Vladimirovich Kurbatov ${ }^{3}$ \\ ${ }^{1}$ Lobachevsky State University of Nizhni Novgorod, Nizhny Novgorod, Russia \\ ${ }^{2}$ Saint Petersburg State University, St.Petersburg, Russia \\ ${ }^{3}$ University of Uppsala (Sweden), Uppsala, Sweden \\ Correspondence: Alexander Ivanovich Gorylev, Lobachevsky State University of Nizhni Novgorod, 603950, pr. \\ Gagarina, 23, Nizhny Novgorod, Russia. E-mail: pr@unn,ru
}

Received: July 30, 2014 Accepted: September 30, 2014 Online Published: December 30, 2014

doi:10.5539/ass.v11n3p218 URL: http://dx.doi.org/10.5539/ass.v11n3p218

\begin{abstract}
The paper is devoted to the analyses of the results of the comparative research of perestroika period representations in Russian textbooks on history. Research design and research results are discussed in a framework of distinction between qualitative and quantitative strategies of comparison. The basic features of qualitative strategy, its strong and weak points are outlined based on the materials of the research. Three discourses of representation of perestroika period in Russian textbooks are identified. The aim of this paper is to discuss comparative advantages and limitations of qualitative strategy of comparison as applied to our study of perestroika period representations in Russian textbooks on history.
\end{abstract}

Keywords: comparative research, case-oriented strategy, variable-oriented strategy, textbook research, post-Soviet nation-building, "domino principle" discourse, "national-awakening" discourse, "feudal macchiavellism" discourse, perestroika period

\section{Introduction}

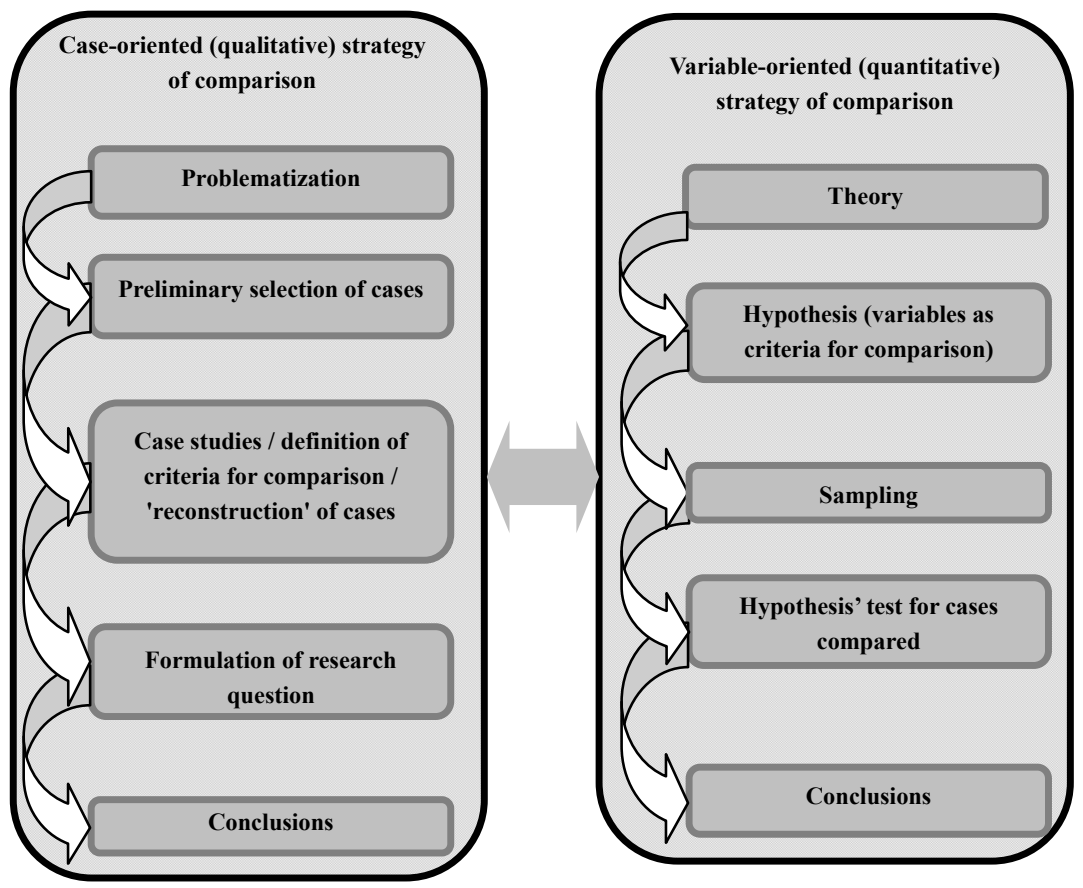

Figure 1. 
Current discussion in comparative sociology points to the two basically different strategies of comparative research: case-oriented (qualitative) and variable-oriented (quantitative) strategies. Their logics of comparison are similar to qualitative and quantitative research design in general (Ragin \& Zaret, 1983). Qualitative strategy starts from general problematization with further exploration of relevant cases and making comparative conclusions. Quantitative strategy starts from particular theoretical question that provides a hypothesis about the connection between general variables and determines the universe of cases to sample with later testing the hypothesis and further conclusions.

There is a debate about advantages and limitations of these strategies. Variable-oriented scholars (Goldthorpe, 1997a; Goldthorpe, 1997b; Lieberson, 1991) argue that case-oriented strategy lacks statistical techniques to assure validity and replaces theoretical work by narration on cases' history. Case-oriented scholars (Goldstone, 1997; Ragin, 1987; Ragin, 1997; Tilly, 1997) claim for more flexible standards of scientific work that include historical narratives and theory construction during the research and criticize quantitative comparative scientists for ignorance of cases' specificity. This discussion is focused on general methodological problems of comparative sociology that could be presented as several dilemmas: abstract variables versus specific historical paths, theory testing versus theory construction, etc. As the result, both sides are pushed to strengthen the argumentation and to improve research methodology. Now it is generally acknowledged that each strategy has its specificity own strong and weak points, so, they could complement each other for concrete research tasks (Ragin \& Zaret, 1983; Rezaev \& Tregubova, 2012; Rezaev, Starikov, \& Tregubova, 2014).

\section{Materials and Methods}

Russian textbooks containing information on perestroika vary greatly in subject, place and year of edition and the audience. Besides, the procedure of their approval is different. School textbooks are recommended or allowed by special bodies of the Ministry of Education and Science of the RF. University textbooks could be approved by merely university committees without direct control of the Ministry, and universities in Russia are also pretty diverse (Avralev \& Efimova, 2014). So, it is extremely difficult to analyze a full body of textbooks. Here we should construct a sample that would comprise their diversity. In order to construct such sample we would follow the certain particular questions or criteria:

1. Is a textbook for pupils or for students?

2. Is a textbook recommended by the Ministry of Education and Science of the RF?

3. What is the region of a university textbook?

4. What is the subject of a textbook?

Therefore, four distinctions would be significant for our analysis. Constructed considering these differences, our sample comprises twenty two textbooks.

They include eight regional textbooks. We identified for study textbooks from Bashkortostan, Tatarstan, Chechnya, Irkutskaya oblast, and Rostovskaya oblast. The two latter regions are intermediate between the centre and the "alternative centres". Rostov-na-Donu is administrative centre of the Southern federal region and Irkutsk in one of the largest centres of Eastern Siberia.

Bashkortostan, Tatarstan and Chechnya are supposed to be "alternative centres". Firstly, they were autonomous republics in the USSR (Chechnya as the part of Chechen-Ingush Autonomous Socialist Republic) and now they are entities of RF with legal status of a republic. Secondly, Chechnya and Tatarstan are the most sensitive to the issue of "national revival" Russian entities. They both refused to sign the Federal Treaty in 1992. During $90^{\mathrm{s}}$ Tatarstan had intensive and controversial negotiations with the Centre and Chechnya was involved in military conflicts (known as Chechen wars). Bashkortostan is chosen as a "control case" since in 1990 it declares the sovereignty but in 1992 signed the Federal Treaty.

To explore chosen textbooks mixed methods design with strong qualitative component was decided to be used as the best suited for the data: discourse analysis of textbooks supplemented by qualitative and quantitative content analysis oriented to results of the former.

Discourse analysis of the textbooks tries to reconstruct the "hidden" logic of historical narration and "driving forces" of history. Our analysis could be defined as critical discourse analysis according to classification of Jorgensen and Phillips (Jorgensen \& Phillips, 2002). The analysis focuses on key points of narration elaborated during the research: the interpretation of perestroika process in general (its preconditions, key actors and logic of narration); characteristic of SU collapse; "portrait" of Gorbachev and description of Chernobyl; description of communist ideology in the SU and of separatism preconditions presented in the discourses. These points are 
"sensitive" to ideological biases and could demonstrate differences in evaluation of perestroika and of history of Fatherland in general. Some of these points, for example, the representation of Gorbachev's activities in textbooks, have already become an object of research (Kurbatov \& Marchenko, 2013).

Table 1. Sample of textbooks for research

\begin{tabular}{|c|c|c|c|c|c|}
\hline & Type of textbook & Title & Author(s) & Place & Year \\
\hline \multirow{14}{*}{ 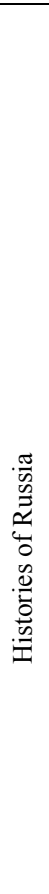 } & \multirow{5}{*}{$\begin{array}{l}\text { Recommended } \\
\text { school textbooks }\end{array}$} & History of Russia. XX century & $\begin{array}{l}\text { N.V. Zagladin, S.T. Minakov, } \\
\text { S.I. Kozlenko, Yu.A. Petrov }\end{array}$ & Moscow, Russkoe slovo & 2007 \\
\hline & & $\begin{array}{c}\text { History of Russia. XX - beginning of } \\
\text { XXI century }\end{array}$ & $\begin{array}{l}\text { N.V. Zagladin, S.T. Minakov, } \\
\text { S.I. Kozlenko, Yu.A. Petrov }\end{array}$ & Moscow, Russkoe slovo & 2007 \\
\hline & & $\begin{array}{c}\text { History of Russia. XX - beginning of } \\
\text { XXI century }\end{array}$ & $\begin{array}{l}\text { A.A.Danivol, L.G. Kosulina, } \\
\text { M.Yu. Brandt }\end{array}$ & $\begin{array}{c}\text { Moscow, } \\
\text { Prosveshcheniye }\end{array}$ & 2012 \\
\hline & & $\begin{array}{c}\text { Russia and World in XX - beginning } \\
\text { of XXI century }\end{array}$ & $\begin{array}{l}\text { L.N. Aleksashkina, A.A. } \\
\text { Danivol, L.G. Kosulina }\end{array}$ & $\begin{array}{l}\text { Moscow, } \\
\text { Prosveshcheniye }\end{array}$ & 2010 \\
\hline & & $\begin{array}{c}\text { History of Russia. XX - beginning of } \\
\text { XXI century }\end{array}$ & $\begin{array}{l}\text { A.A. Levandovsliy, Yu.A. } \\
\text { Shchetinov, S.V. Mironenko }\end{array}$ & $\begin{array}{c}\text { Moscow, } \\
\text { Prosveshcheniye }\end{array}$ & 2011 \\
\hline & \multirow{3}{*}{$\begin{array}{l}\text { Non-recommended } \\
\text { school textbooks }\end{array}$} & History of Russia. XX century & A.A. Danivol, L.G. Kosulina & $\begin{array}{c}\text { Moscow, } \\
\text { Prosveshcheniye }\end{array}$ & 1995 \\
\hline & & $\begin{array}{c}\text { History of Russia. XX - beginning of } \\
\text { XXI century }\end{array}$ & $\begin{array}{l}\text { A.A. Danivol, L.G. Kosulina, } \\
\text { A.V. Pyzhikov }\end{array}$ & $\begin{array}{c}\text { Moscow, } \\
\text { Prosveshcheniye }\end{array}$ & 2003 \\
\hline & & Russia in XX century & $\begin{array}{l}\text { A.A. Levandovsliy, } \\
\text { Yu.A. Shchetinov }\end{array}$ & $\begin{array}{l}\text { Moscow, } \\
\text { Prosveshcheniye }\end{array}$ & 1997 \\
\hline & \multirow{6}{*}{$\begin{array}{l}\text { Central university } \\
\text { textbooks }\end{array}$} & History of Russia. 1917-2009 & A.S. Barsenkov, A.I. Vdovin & Moscow, Aspekt-Press & 2010 \\
\hline & & History of Russia. XX century & V.P. Dmitrienko (Ed.) & Moscow, AST & 1998 \\
\hline & & History of Russia & $\begin{array}{l}\text { A.S. Orlov, V.A. Georgiev, } \\
\text { N.G. Georgieva. T.A. Sivihina }\end{array}$ & Moscow, Prospect & 1997 \\
\hline & & History of Russia & V.V. Kirillov & Moscow, ID Uriht & 2011 \\
\hline & & History of Russia & E.V. Lapteva & $\begin{array}{c}\text { Moscow, Akadem. } \\
\text { proekt }\end{array}$ & 2009 \\
\hline & & History of Fatherland & V.P. Semin & $\begin{array}{l}\text { Moscow, Akadem. } \\
\text { proekt, Gaudeamus }\end{array}$ & 2008 \\
\hline \multirow{8}{*}{ 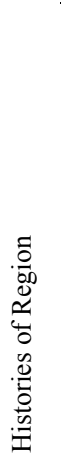 } & \multirow{8}{*}{$\begin{array}{l}\text { Regional university } \\
\text { textbooks }\end{array}$} & $\begin{array}{c}\text { History of Russia in questions and } \\
\text { answers }\end{array}$ & S.A. Kislitsin & Rostov-na-Donu, Fenix & 1997 \\
\hline & & History of Russia. XX century & K.B. Valiullin, R.K. Zaripova & Ufa, RIO BashGU & 2002 \\
\hline & & $\begin{array}{l}\text { History of Fatherland. Part II (mid of } \\
\text { XIX - end of XX century) }\end{array}$ & T.S. Konukov (ed.) & Ufa, UfGATU & 1995 \\
\hline & & History of Fatherland & O.M. Bobyleva & Irkutsk, IrGUPS & 2010 \\
\hline & & $\begin{array}{c}\text { History of Bashkortostan } \\
(1917-1990 \mathrm{~s})\end{array}$ & R.Z. Yanguzin (ed.) & Ufa, BasshGU & 1997 \\
\hline & & $\begin{array}{l}\text { History of Tatarstan from ancient } \\
\text { times till our days }\end{array}$ & $\begin{array}{l}\text { D.K. Sabirova, Ya.Sh. } \\
\text { Sharapov }\end{array}$ & Moscow, KnoRus & 2009 \\
\hline & & History of Tatarstan & B.F. Sultanbekov (ed.) & Kazan, TaRih & 2001 \\
\hline & & $\begin{array}{l}\text { History if Chechnya in XIX-XX } \\
\text { centuries }\end{array}$ & $\begin{array}{l}\text { Ya.Z. Ahmadov, } \\
\text { E.H. Hasmagomadov }\end{array}$ & Moscow, Puls & 2005 \\
\hline
\end{tabular}

Content analysis of the textbooks corroborates discourse analysis and is oriented toward its results. Qualitative content analysis studies definitions of perestroika and the names of textbooks sections devoted to perestroika. Quantitative content analysis concerns the total number of pages on perestroika and on different topics of narration. It is completed for four categories that promise to be characteristic for the differences between revealed discourses as well as for further comparisons between countries: personalities, institutions and organisations, countries and events.

\section{Results}

Characteristics of perestroika period is given about 18 pages of textbook and about $4 \%$ of the total volume in average, and 16 out of 22 textbooks contain special paragraph or sub-paragraph on this period. So, the significance of the topic for textbooks is evident.

The most often mentioned figure in textbooks is, not surprisingly, Mikhail Gorbachev with 396 mentions. The second figure, Boris Yeltsyn is mentioned more then two times less, 167. Organization that is named more often is the Communist Party of the Soviet Union that is mentioned 391 times, as often as Gorbachev. Other 
personalities and organizations are named strikingly less often. As for the countries, the most mentioned one is the USSR with 839 mentions, and the next is Russia/RSFSR that is named 322 times.

Discourse and content analysis of textbooks reveal three separate discourses in narration on perestroika. The most popular is discourse that is peculiar to all "Histories of Russia" and to the "History of Bashkortostan" as well. It was named "domino principle" discourse that refers to domino principle - a chain reaction that occurs when a small change causes a number of following changes. It typically refers to a linked sequence of events where the time between successive events is relatively small.

"Domino principle" discourse regards perestroika as a time period started with the reforms that had unexpected consequences and resulted in the USSR collapse. So, the process is depicted as an analogy to a falling row of dominoes started with modest reforms and arrived at state disintegration. The discourse focuses on the all-Soviet level and points to political figures as main actors with Gorbachev and CPSU as the most important.

Two other discourses "deviated" from the main one and could be discovered in the "History of Chechnya" and in the "Histories of Tatarstan", respectively. For the discourse of the "History of Chechnya" we propose the author's term "feudal Macchiavellism". "Macchavellism" refers to its focus on ethnopolitical struggle of elites at the regional level where perestroika plays a role of a mere "trigger". "Feudal" refers to the narration that presents Checheno-Ingushetia as the part of the USSR but rather as a "feudal principality" that got a chance to gain more autonomy because of the weakening of the suzerain, the SU.

The "Histories of Tatarstan" demonstrate "national awakening" discourse that starts with the same characteristic of perestroika as "domino principle" discourse. Later the focus is shifted from perestroika and the SU in general to the level of Tatarstan and to the processes on national awakening and development of separatism movement. It presents a different kind of separatism that is synonymous to democratic movement and points to civil nation and to Tatarstan as state-like entity.

Thus, the one of the four sample distinctions was relevant for the way perestroika is represented - the region. Among the regional diversity only polar cases with separatist tendencies, Chechnya and Tatarstan, demonstrated significant difference as opposed to the rest of textbooks. This difference is so striking that the cases should be redefined: instead of one case of Russia we get three cases with three distinct discourses.

Research results impel to specify initial problematization of the research to more focused research problem concerning the distinctiveness of Chechnya and Tatarstan cases. It was formulated as problem of nation-building in post-Soviet space via the study of representation of perestroika in textbooks.

It is more difficult to make final comparison for qualitative strategy of comparison then for its counterpart. Case-oriented strategy implies descriptions of cases with unique features while variable-oriented strategy studies only those aspects of objects that are connected with the hypothesis. That is why many insights on perestroika representation in each case are unique and incomparable. However, the guiding research question helps to provide generalizations.

The peculiarity of the main discourse is its invariable focus on all-Soviet level. In comparisons with Chechen and Tatarstan textbooks it is clear that there is a possibility to focus on the RSFSR or to shift from the SU to Russia during the narration. However, the history presented is the history of the USSR. This country is presented as the predecessor of contemporary Russia.

The next question could be the following: what does Soviet Russia (the RSFSR) mean in the textbooks? Speculating on ethnic tensions, Russian textbooks always start with the situation in national republics and describe Russian "response" on them. Moreover, for the RSFSR "quasi-separatism" is portrayed that implies just radical democratic and market reforms for the SU in general and, again, no specific for Russia itself. Therefore, the textbooks of the main discourse are "blind" when they see such actors as centre (above nationality) and national (ethnic) entities. Russia itself as equal region subordinate to centre is defined as the "remainder" (while from the point of view of Chechnya, for instance, it is equal to centre). This strange configuration implies reification of center and periphery and of distinct nations with unclear status of Russia per se.

\section{Discussion}

Political composition of the RF influences this configuration because it is reproduced in description of perestroika as well as in contemporary situation. We could notice analogies between the SU - "national republics" -the RSFSR and the RF - "national regions" -"the rest of Russia". This configuration enables to perceive the history as continuous from the SU to Russia. So, actual structure of the RF and contemporary Russian identity are formed by Soviet nation-building processes (A State of Nations. Empire and Nation-making in the Age of Lenin \& Stalin, 2001; Martin, 2001). They implied institutionalization of ethnic nations at sub-state levels (union 
republics, autonomous republics, etc.). During Soviet time Russian nation was less institutionalized by absence of the regional Communist party as a place of elite formation and great regional diversity of the republic. At the same time it was a kind of "umbrella" for all-country country identity. As a result, Russians became to associate themselves (and by others) with the Soviet in general.

As for other discourses they also construct their own identity conforming to their context. Tatarstan is the only entity that has an agreement with the Centre providing broader autonomy. So, its textbooks points to civil nationalism. It resembles a Russian doll, "state inside state", but, as this kind of separatism reifies ethnicity, Tatars possess definite status and have a priority as a cause of specificity of the region. As for Chechnya, its separatism does not point to any state-like entity but rather refers to feudal relations with the Centre and focuses on tensions inside the region. It is possibly accounted for the lack of self-consciousness as single nation (in ethnic or civil sense) when relations between Chechens are more important then relations with foreigners.

So, the representations of perestroika reveal different logics and strategies of nation-building in post-Soviet space. These logics imply self-identification through continuation (Russia) or dissociation (Chechnya, in part Tatarstan) with the USSR. Therefore, discursive space of post-Soviet nation-building is constituted by the triangular "The USSR - the case - Russia" with specific relation between each pair of the elements. This configuration could be supplemented by several elements crucial for particular region as predecessor, counterpart or antagonist (e.g., the Golden Horde) but they only help to answer two basic (and interconnected) questions posed by the triangular: What is the status of the case "whose" history is narrated? What are the relations between the case, the USSR and Russia?

\section{Conclusion}

The basic advantage of comparative design in qualitative strategy, as our research demonstrates, is flexibility to formulate research question and to define case borders according to specificity of unique cases under consideration. The research starts from "pure" description, and then discovers significant differences that help to formulate the problem demanding explanation. Such preliminary explanation provides general framework for further comparative study.

However, focus on specific cases studies could not reveal a typical, "textbook" case of post-Soviet nation building in general. It is unclear whether the "domino principle" discourse is such widespread in other post-Soviet countries as in Russia and whether "deviant" discourses are "deviant" indeed. Moreover, nothing could be stated about possible amount and variety of perestroika representations in post-Soviet space. To discover typical patterns we need to extend comparative study to include various cases in more variable-oriented manner. With the most similar cases of Russia we discovered diversity in similarity. The most different cases could help to look for variety of answers to the two primary questions via textbook study and to find similarity in diversity

\section{Acknowledgments}

The article is prepared under the project "Internationalization and Implementation of Western Educational Standards in the Post-Soviet States: From Building a Network Toward Joint Research", which received funding from Swedish Institute.

\section{References}

A State of Nations. (2001). Empire and Nation-making in the Age of Lenin and Stalin. Oxford University Press.

Avralev N., \& Efimova, I. (2014). Global university rankings as indicators of the implementation of the integration process and competitive tool in the context of globalization of higher education. Life Sci J., 11(10), 648-652.

Goldstone, J. (1997a). Methodological Issues in Comparative Macrosociology. Comparative Methodological Research. Methodological Issues in Comparative Science, 16, 107-120.

Goldthorpe, J. (1997b). Current Issues in Comparative Macrosociology: A Debate on Methodological Issues. Comparative Methodological Research. Methodological Issues in Comparative Science, 16, 1-26.

Goldthorpe, J. (1997c). Current Issues in Comparatives Macrosociology: A Response to the Commentaries. Comparative Methodological Research. Methodological Issues in Comparative Science, 16, 121-132.

Jorgensen, M., \& Phillips, L. J. (2002). Discourse Analysis as Theory and Method. Sage Publications (p. 229).

Kurbatov S., \& Marchenko, A. (2013). Diversification of the "Late Soviet": Attitudes to Mikhail Gorbachev in the Mirrors of History Textbooks. The Ideology and Politics Journal, 2(4), 4-28. 
Lieberson, S. (1991). Small N's and Big Conclusions: An Examination of the Reasoning in Comparative Studies Based on a Small Number of Cases. Social Forces, 70(2), 307-320. http://dx.doi.org/10.1093/sf/70.2.307

Martin, T. (2001). The Affirmative Action Empire (p. 528). Cornell University Press.

Ragin, C. (1987). The Comparative Method: Moving beyond Qualitative and Quantitative Strategies (p. 185). The Regents of the University of California.

Ragin, C. (1997). Turning the Tables: How Case-Oriented Research Challenges Variable-Oriented Research. Comparative Methodological Research. Methodological Issues in Comparative Science, 16, 27-42.

Ragin, C., \& Zaret, D. (1983). Theory and Method in Comparative Research: Two Strategies. Social Forces, 61(3), 731-754. http://dx.doi.org/10.1093/sf/61.3.731

Rezaev, A. V., \& Tregubova, N. D. (2012). Comparative analysis in sociology: Levels of application and conceptual problems. Journal of Sociology and Social Anthropology, 4(63), 44-62.

Rezaev, A. V., Starikov, V. S., \& Tregubova, N. D. (2014). Comparative sociology: current status and future directions. Sociological Journal, 2, 89-112.

Tilly, C. (1997). Means and Ends of Comparison in Macrosociology. Comparative Methodological Research. Methodological Issues in Comparative Science, 16, 43-53.

\section{Copyrights}

Copyright for this article is retained by the author(s), with first publication rights granted to the journal.

This is an open-access article distributed under the terms and conditions of the Creative Commons Attribution license (http://creativecommons.org/licenses/by/3.0/). 